\title{
PREVALENCE OF AND MORTALITY FROM CORONARY ARTERY DISEASE IN MEN
}

\author{
BY \\ R. G. RECORD AND A. G. W. WHITFIELD \\ From the Medical School, University of Birmingham
}

It is generally believed that the frequency of coronary artery disease has increased greatly during the present century in all countries which enjoy a high standard of living. The most recent statistics published by the Registrar General show that, in England and Wales in 1962, it was the major cause of death in men in every age group from 40 to 79 and accounted for almost a quarter of all deaths of men aged 30 and over (Table I). It now surpasses both malignant disease and other heart disease which were formerly commoner causes. Campbell (1963) has shown, however, that during the decade $1950-59$ the increase in coronary deaths was balanced by a decrease in deaths due to other diseases of the myocardium and he suggests that there has been no true increase in coronary disease during this period.

The first part of the present paper is concerned with an exploration of this problem. The second part deals with the prevalence of the disease and its mortality in men of a particular age group (60-69 years).

\section{Changes in Mortality ascribed to Coronary ArTERY Disease}

The examination of secular trends in mortality is notoriously treacherous ground and this is particularly true in the case of coronary disease which seems

TABLE I

DEATH RATES (PER 1,000) OF MEN, BY CAUSE AND AGE, ENGLAND AND WALES, 1962

\begin{tabular}{|c|c|c|c|c|c|c|c|c|c|c|c|c|c|c|c|}
\hline \multirow[b]{2}{*}{$\begin{array}{l}\text { I.S.C. } \\
\text { Code }\end{array}$} & \multirow[b]{2}{*}{ Cause of Death } & \multicolumn{12}{|c|}{ Age (yrs) } & \multicolumn{2}{|c|}{$\begin{array}{l}\text { All Ages } 30 \text { and } \\
\text { Over }\end{array}$} \\
\hline & & $30-$ & $35-$ & 40 & 45- & 50 & $55-$ & 60 & $65-$ & $70-$ & $75-$ & $80-$ & $85-$ & $\begin{array}{l}\text { No. of } \\
\text { Deaths }\end{array}$ & $\begin{array}{c}\text { Per- } \\
\text { centage } \\
\text { Distribu- } \\
\text { tion }\end{array}$ \\
\hline $\begin{array}{l}420.1 \\
420.2\end{array}$ & $\begin{array}{l}\text { Heart disease invol- } \\
\text { ving coronary } \\
\text { arteries; angina } \\
\text { pectoris }\end{array}$ & $0.09 \mid$ & $0 \cdot 34 \mid$ & 0.74 & $1 \cdot 50$ & $2 \cdot 76$ & $5 \cdot 00$ & $8 \cdot 10$ & $11 \cdot 68$ & $16 \cdot 83$ & $21 \cdot 32$ & $27 \cdot 27$ & $32 \cdot 53$ & 61,955 & $23 \cdot 2$ \\
\hline $330-334$ & $\begin{array}{l}\text { Vascular lesions of } \\
\text { central nervous } \\
\text { system }\end{array}$ & 0.05 & 0.08 & 0.15 & $0 \cdot 29$ & $0 \cdot 60$ & $1 \cdot 24$ & $2 \cdot 47$ & $4 \cdot 84$ & $9 \cdot 08$ & $15 \cdot 75$ & $26 \cdot 77$ & $42 \cdot 03$ & 31,529 & $11 \cdot 8$ \\
\hline $\begin{array}{l}400-416 \\
420.0 \\
421-468\end{array}$ & $\begin{array}{l}\text { Other diseases of } \\
\text { circulatory system }\end{array}$ & $0 \cdot 10$ & $0 \cdot 19$ & $0 \cdot 28$ & 0.46 & 0.76 & $1 \cdot 45$ & $2 \cdot 76$ & 5.05 & $10 \cdot 48$ & $20 \cdot 26$ & $42 \cdot 39$ & $86 \cdot 44$ & 43,189 & $16 \cdot 2$ \\
\hline $140-205$ & $\begin{array}{l}\text { Malignant neo- } \\
\text { plasms }\end{array}$ & $0 \cdot 21$ & 0.36 & 0.64 & $1 \cdot 34$ & $2 \cdot 62$ & $4 \cdot 83$ & $7 \cdot 77$ & $10 \cdot 48$ & $13 \cdot 87$ & $16 \cdot 96$ & $19 \cdot 91$ & $20 \cdot 25$ & 53,766 & $20 \cdot 1$ \\
\hline $\begin{array}{l}490-493 \\
500-502\end{array}$ & $\begin{array}{l}\text { Pneumonia; bron- } \\
\text { chitis }\end{array}$ & 0.05 & 0.08 & $0 \cdot 17$ & 0.36 & 0.79 & $1 \cdot 84$ & $3 \cdot 90$ & $6 \cdot 24$ & $10 \cdot 15$ & $15 \cdot 87$ & $25 \cdot 22$ & $41 \cdot 48$ & 35,972 & $13 \cdot 5$ \\
\hline E800-E999 & $\begin{array}{l}\text { Accidents; poison- } \\
\text { ings; violence }\end{array}$ & 0.41 & 0.45 & 0.50 & 0.56 & 0.61 & 0.71 & 0.87 & 0.94 & $1 \cdot 42$ & $2 \cdot 11$ & $3 \cdot 84$ & $6 \cdot 69$ & 9,823 & $3 \cdot 7$ \\
\hline Remainder & Other causes & 0.28 & 0.35 & 0.47 & 0.71 & $1 \cdot 13$ & $1 \cdot 81$ & $3 \cdot 01$ & $4 \cdot 56$ & $7 \cdot 28$ & $11 \cdot 07$ & $19 \cdot 15$ & $37 \cdot 93$ & 30,746 & $11 \cdot 5$ \\
\hline \multicolumn{2}{|c|}{$\begin{array}{cc}\text { All Causes } . . & . \\
\end{array}$} & $1 \cdot 19$ & $1 \cdot 85$ & 2.95 & $5 \cdot 22$ & $9 \cdot 27$ & $16 \cdot 88$ & $28 \cdot 88$ & $43 \cdot 79$ & $69 \cdot 11$ & $103 \cdot 34$ & $164 \cdot 55$ & $267 \cdot 35$ & 266,980 & $100 \cdot 0$ \\
\hline \multicolumn{2}{|c|}{$\begin{array}{c}\text { Percentage of deaths due to } \\
\text { Coronary Disease }\end{array}$} & 8 & 18 & 25 & 29 & 30 & 30 & 28 & 27 & 24 & 21 & 17 & 12 & & \\
\hline
\end{tabular}


to have been rarely recognized until the present century. Difficulties may arise in three ways:

(1) Changes in the Age Structure of the Population.-This is readily overcome by standardizing for age or by restricting attention to age-specific rates.

(2) Changes in Classification and in Rules for deciding the Principal Cause of Death.-The classification used since 1958 by the Registrar General is the Seventh Revision of the "International Statistical Classification of Diseases, Injuries, and Causes of Death" (1955). This differs only slightly from the Sixth Revision (1948) which was in use during the years 1950-57, and the effect of the changes can be easily corrected by applying comparability factors published in 1959 in the Registrar General's "Statistical Review of England and Wales for the Year 1957" (Part III, Appendix B). It is therefore possible to compare the mortality rates for 1950 and 1962 with some confidence, but the different classification in use before 1950 makes comparison over a longer period less reliable.

(3) Changes in Diagnostic Practice.-Advances in medical knowledge, more diagnostic equipment, and more frequent resort to post mortem examination undoubtedly permit a more precise diagnosis of heart diseases than was formerly possible. It may be expected, therefore, that relatively vague terms, such as myocardial degeneration, hypertension, or functional heart disease, would be used with decreasing frequency and that more specific diagnoses such as coronary thrombosis would be preferred. If this were so, mortality trends would show an apparent transfer of deaths from one category to another. A decision whether there has been an increase in mortality due to coronary artery disease must therefore depend on an examination of statistics relating to other causes of death which may have been confused with coronary disease more frequently in the past than now. The following rubrics of the current classification (with their code numbers in brackets) merit such consideration:

Arterio-sclerotic heart disease so described (420.0).

Chronic endocarditis not specified as rheumatic (421)

Other myocardial degeneration (422)

Functional heart disease (433)

Other and unspecified heart disease (434)

Hypertensive heart disease (440-443)

Other hypertensive disease (444-447)

The change in mortality rates ascribed to these diseases between 1950 and 1962 is compared in Table II with the change in the rate of coronary artery disease (rubrics $\mathbf{4 2 0 . 1}$ and $\mathbf{4 2 0 . 2}$ of the International Classification). The crude rates show a considerable increase $(1.95$ per 1,000$)$ in mortality ascribed to coronary artery disease and a moderate decrease $(1.38$ per 1,000$)$ in mortality due to the other heart diseases listed above. But when differences in the age structure of the population are taken into account by standardizing the 1962 rates to the 1950 population, the coronary increase $(1 \cdot 68)$ is not very different from the decrease shown by the other diseases $(1 \cdot 57)$.

TABLE II

MORTALITY RATES (per 1,000) FROM CORONARY ARTERY DISEASE AND CERTAIN OTHER HEART DISEASES* IN MEN AGED 30 AND OVER

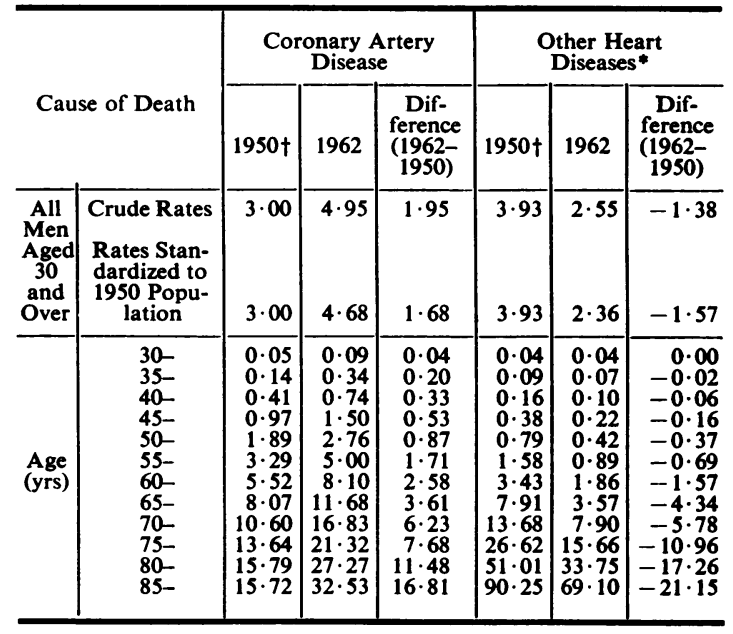

* Listed in text.

tComparability factors have been applied to the 1950 rates to adjust for changes in the classification (see Registrar General's "Statistical Review, 1957", Pt. III, Appendix B).

At first sight this supports the view that nearly all the increase in coronary deaths could be attributed to a transfer of deaths from other parts of the classification; but a different conclusion is drawn when the age-specific rates shown in Table II are compared. In every age group from 30 to 64 and at 70-74 the increase in coronary deaths exceeded the decrease in deaths due to other heart diseases. It seems clear then that only part of the increase in coronary deaths can be attributed to transfers from other causes. It is concluded that, in men up to late middle age at least, there has been a substantial increase in deaths from coronary heart disease even over so short a period as 13 years.

It is of some interest to compare these results with changes in male mortality from vascular lesions of the central nervous system during the same period. Age-specific rates show only trivial changes up to 
age 59, slight decreases between 60 and 74, and increases at 75 and over. Although both coronary disease and cerebro-vascular disease are often associated with hypertension, this result suggests a considerable difference in the pathogenesis of these two groups of diseases.

\section{Prevalence and Mortality of Coronary}

ArTery Disease in Men AGed 60-69 Years

The evidence examined in the preceding section suggests that the recorded increase in mortality from coronary artery disease in recent years is due both to a real increase in deaths from this disease and to its better recognition, some deaths which would formerly have been ascribed to other heart conditions now being more accurately certified as due to coronary disease. But it is still by no means certain that all such deaths are properly allocated and it may well be that the current mortality figures underestimate the importance of this condition. Another limitation of mortality statistics is that they may not be a reliable guide to the prevalence of coronary disease in the population or to the risk of an individual developing it. This is because of its unpredictable course, which may vary from one so abrupt that death may be almost the first manifestation of the disease to one so prolonged that the patient may die from some unrelated cause before the coronary condition becomes lethal.

It is not unduly difficult to assess the prevalence of the disease in a population at a single point in time or to follow for a period a group of cases which have been treated in hospital; the literature contains a number of reports of both sorts of survey. Much useful information is thus obtained, but both types of investigation have their limitations: the first because it ignores the time factor, and the second because it is based on selected material. It is much more difficult to keep a population under review for a period long enough not only to assess the progress of the established disease but also to observe the emergence and development of new cases. The present communication reports such an attempt, but it was carried out on a somewhat limited scale, being restricted to a 5-year survey of men of a particular age group.

\section{MATERIAL}

In 1956, eleven Birmingham general practitioners examined all men aged 60-69 on their lists (Brown, Davidson, McKeown, and Whitfield, 1957). Of the 1,062 men examined, 109 were considered to show evidence of coronary artery disease and were referred to one of us (A.G.W.W.) who carried out a full clinical examination, including chest radiography and electrocardiography. The diagnosis was confirmed in 89.

3 years later a re-examination of all these men was attempted; 117 had died and twenty could not be traced, but the remaining 925 were examined by their doctors who also reported thirty new cases of coronary disease. From the experience of the first survey (when the doctors' opinions were confirmed in 82 per cent. of cases) it was thought that on this occasion referral to a consultant was a refinement that could reasonably be dispensed with.

Five years after the first survey a follow-up not involving examination was carried out; 825 men were known to be alive, ninety had died since the second survey, and ten could not be traced.

\section{RESULTS}

The numbers identified at each survey and the deaths which occurred in the two intervals are indicated in the Figure (opposite).

The plan of the investigation permits observations to be made on the three following groups:

(1) 87 of the 89 men found to have coronary artery disease at the first survey. The data include new episodes of the disease arising during 3 years, and the 5-year mortality of these men.

(2) New cases of coronary artery disease arising during 3 years among 955 of the 973 men with no evidence of the disease at the first survey.

(3) New fatal cases occurring in the last 2 years of the investigation.

(1) Men found to have Coronary Artery Disease at the First Survey.-The experience of these men during the 3 years after the first survey is shown in Table III (opposite). Of the 38 men with angina but no infarction, 37 were followed for 3 years. During this time two men had two infarctions each and survived, and five had one infarction, three of these being fatal. Two of the remaining thirty men had died from other conditions. Of the 39 men who had had one or more myocardial infarction before the first survey, four had another one and two of these men died; five of the remaining 35 men had also died. Eleven of the twelve men with other coronary disease were traced. Two had had an infarction, with a fatal result in both cases, and two other men had died.

Thus in the whole series, sixteen men died in the 3 years; the total number of infarctions experienced 


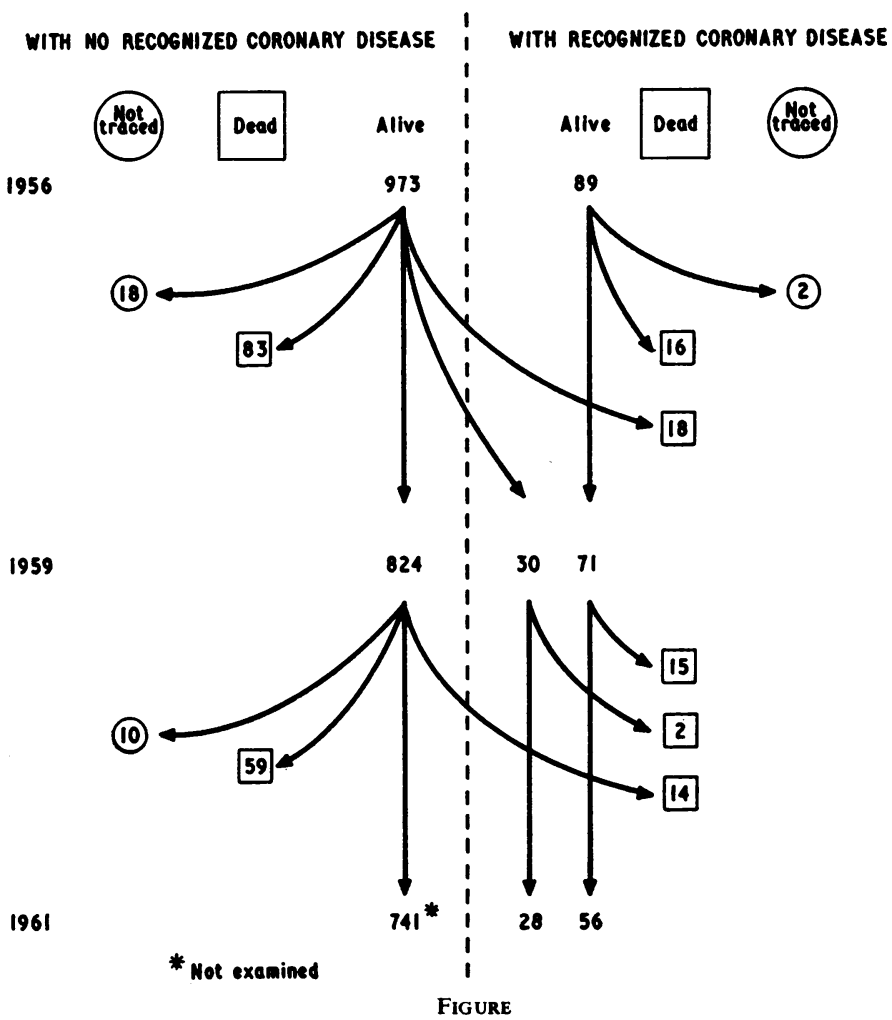

TABLE III

FREQUENCY OF MYOCARDIAL INFARCTION IN MEN WITH CORONARY ARTERY DISEASE IN 1956

\begin{tabular}{|c|c|c|c|c|c|}
\hline \multirow{2}{*}{$\begin{array}{l}\text { Condition at First } \\
\text { Survey (1956) }\end{array}$} & \multirow{2}{*}{$\begin{array}{l}\text { No. } \\
\text { of } \\
\text { Men }\end{array}$} & \multicolumn{4}{|c|}{$\begin{array}{l}\text { No. of Myocardial Infarctions, } \\
1956-59\end{array}$} \\
\hline & & $\mathbf{0}$ & 1 & 2 & Unknown \\
\hline $\begin{array}{c}\text { Angina; no history of } \\
\text { infarction }\end{array}$ & $\begin{array}{l}38 \\
(5)\end{array}$ & $\begin{array}{l}30 \\
(2)\end{array}$ & $\begin{array}{r}5 \\
(3)\end{array}$ & $\stackrel{2}{(0)}$ & 1 \\
\hline One infarction & $\begin{array}{l}35 \\
(6)\end{array}$ & $\begin{array}{l}32 \\
(5)\end{array}$ & $(1)$ & - & - \\
\hline Two infarctions & (1) & $\begin{array}{l}3 \\
(0)\end{array}$ & (1) & - & - \\
\hline $\begin{array}{c}\text { Other coronary artery } \\
\text { disease }\end{array}$ & (4) & $\begin{array}{r}9 \\
(2)\end{array}$ & $\begin{array}{r}2 \\
(2)\end{array}$ & - & 1 \\
\hline Total .. & $\begin{array}{l}89 \\
(16)\end{array}$ & $\begin{array}{l}74 \\
(9)\end{array}$ & $\begin{array}{l}11 \\
(7)\end{array}$ & $\begin{array}{r}2 \\
(0)\end{array}$ & 2 \\
\hline
\end{tabular}

(The figures in parentheses indicate the number of these men who died in the period 1956-59.)

by these men was three (1 man), two (1 man), one (10 men), and none (4 men). Of the 71 who were alive, seven had had two infarctions each, 29 had had one, and 35 had had none.
The follow-up in 1961 enabled 5-year mortality rates to be calculated (Table IV). Not unexpectedly these rates are high-over one-third of the men had died-but it was surprising to find that those who had angina only in 1956 had a higher death rate than those who had then sustained infarctions. This is partly due to the fact that they tended to be older (47 per cent. were aged 65-69 compared with 33 per

TABLE IV

DEATHS WITHIN 5 YEARS OF MEN WITH CORONARY ARTERY DISEASE IN 1956

\begin{tabular}{|c|c|c|c|c|c|}
\hline \multirow[b]{2}{*}{$\begin{array}{l}\text { Condition at First } \\
\text { Survey (1956) }\end{array}$} & \multirow[b]{2}{*}{$\begin{array}{c}\text { No. } \\
\text { of } \\
\text { Men }\end{array}$} & \multicolumn{3}{|c|}{ Deaths in Period 1956-61 } & \multirow{2}{*}{$\begin{array}{c}\text { 5-year } \\
\text { Mortality } \\
\text { Rate per } \\
1,000\end{array}$} \\
\hline & & $\begin{array}{c}\text { Due to } \\
\text { Coronary } \\
\text { Disease }\end{array}$ & $\begin{array}{l}\text { Due to } \\
\text { Other } \\
\text { Causes }\end{array}$ & Total & \\
\hline $\begin{array}{l}\text { Angina; no history } \\
\text { of infarction . } \\
\text { Myocardial infarc- } \\
\text { tion . } \\
\text { Other coronary } \\
\text { artery disease }\end{array}$ & $\begin{array}{l}38 * \\
39 \\
12 *\end{array}$ & $\begin{array}{r}9 \\
10 \\
2\end{array}$ & $\begin{array}{l}2 \\
3\end{array}$ & $\begin{array}{c}14 t \\
12 \\
5\end{array}$ & $\begin{array}{l}373 \\
308\end{array}$ \\
\hline Total & 89 & 21 & 8 & $31 t$ & 352 \\
\hline
\end{tabular}

* Includes one man untraced in 1961. † Includes two deaths of unknown cause. 
cent. for the infarction series) but is mainly a reflection of the very high mortality observed among the older men with angina-eleven of the eighteen men aged 65-69 with angina died.

It is interesting to note that only 21 of the 29 deaths of known cause were ascribed to coronary artery disease. The remainder were due to cerebro-vascular disease (2), carcinoma of the lung (2), pneumonia and bronchitis (2), chronic bronchitis (1), and nephrosis (1).

(2) New Cases arising within the 3 years, 1956-59.The number of men without recognized coronary artery disease at the first survey was 973 . At the second survey 3 years later, eighteen of these could could not be traced and 101 had died; fourteen of these deaths were ascribed to coronary thrombosis and one to coronary insufficiency, while two men with angina and one who had had a myocardial infarction had died from other causes. Of the 854 survivors, nineteen were considered by their doctors to have developed angina, and eleven had had a myocardial infarction which they had survived. Before the final follow-up in 1961, one of the men with angina had died of coronary thrombosis and one of the men with infarction had died of cerebral haemorrhage.

Mortality rates (up to 1961) are shown in Table V. The rates relating to infarction are, of course, considerably higher than those shown in Table IV, which was based on men who had survived the immediate dangers of the attack. On the other hand the angina mortality rates are lower, presumably because manifestation of the disease was more recent in the second group than the first and because these men were at risk for a shorter time.

TABLE V

NEW CASES OF CORONARY ARTERY DISEASE ARISING IN PERIOD 1956-59

\begin{tabular}{|c|c|c|c|c|c|}
\hline \multirow[b]{2}{*}{ Diagnosis } & \multirow{2}{*}{$\begin{array}{c}\text { No. } \\
\text { of } \\
\text { Men }\end{array}$} & \multicolumn{3}{|c|}{ Deaths by 1961} & \multirow{2}{*}{$\begin{array}{c}\text { Mortality } \\
\text { Rate per } \\
1,000\end{array}$} \\
\hline & & $\begin{array}{l}\text { Due to } \\
\text { Coronary } \\
\text { Disease }\end{array}$ & $\begin{array}{l}\text { Due to } \\
\text { Other } \\
\text { Causes }\end{array}$ & Total & \\
\hline $\begin{array}{l}\text { Angina: no history } \\
\text { of infarction ... } \\
\text { One infarction ... } \\
\text { Two infarctions .. } \\
\text { Three infarctions } \\
\text { Other coronary } \\
\text { artery disease }\end{array}$ & $\begin{array}{r}21 \\
24 \\
1 \\
1 \\
1\end{array}$ & $\begin{array}{r}1 \\
13 \\
1 \\
0 \\
1\end{array}$ & $\begin{array}{l}2 \\
2 \\
0 \\
0 \\
0\end{array}$ & $\begin{array}{r}3 \\
15 \\
1 \\
0 \\
1\end{array}$ & $\begin{array}{l}143 \\
615\end{array}$ \\
\hline Total & 48 & 16 & 4 & 20 & 417 \\
\hline
\end{tabular}

(3) New Cases arising during the 2 years, 1959-61.The plan of the investigation permitted only fatal cases to be identified in this period. There were 814 men with no recognized coronary artery disease at the second survey who were traced; fourteen had died from coronary disease. Undoubtedly some of the 741 men who survived to 1961 would have been found to show evidence of the disease had they been examined.

\section{Relation of Coronary Artery Disease to Arterial Pressure}

It is generally believed that coronary disease is more likely to arise in persons with hypertension than in those with normal blood pressure. Support for this view is easily obtained by measuring the pressures of patients with angina, but such observations are less useful in cases of infarction because they are based on patients who survive the immediate effects of the occlusion and because infarction is believed to result in a lowering of pressure. This was suggested in the first survey (Brown and others, 1957) where it was found that the mean pressure of men who had had infarctions $(152 / 86)$ was less than that of men without coronary disease $(162 / 90)$, but that the mean pressure of men with other manifestations of coronary disease was higher (173/96).

The two subsequent surveys indentified 62 men who first manifested the disease after their pressures were measured at the first survey; 35 of these had onece or more infarctions. Also of interest is the group of 48 men who at the first survey had evidence of coronary disease but had not then had an infarction; twelve of these men had an infarction later. Mean pressures of these groups are shown in Table VI (opposite).

The numbers are too small to permit detailed interpretation but the results suggest that men who later developed coronary disease have higher pressures than those who did not. These findings are consistent with previous reports (Kannel, Dawber, Kagan, Revotskie, and Stokes, 1961; Yano and Ueda, 1963). Among men who developed coronary disease, there seems to be little difference in mean pressure between those who later suffered an infarction and the rest, apart from a slight suggestion that infarction was less likely in cases with a high diastolic pressure.

Although the mean pressures of those who developed coronary disease were high, a number of these men had pressures which would be regarded as normal at this age. It seems that measurements of arterial pressure are of limited value in identifying men likely to develop coronary disease. The prognostic limitations of these readings are also illustrated by dividing the men with coronary disease detailed in Table VI into those who survived the 
TABLE VI

MEAN ARTERIAL PRESSURE OF MEN AT FIRST SURVEY

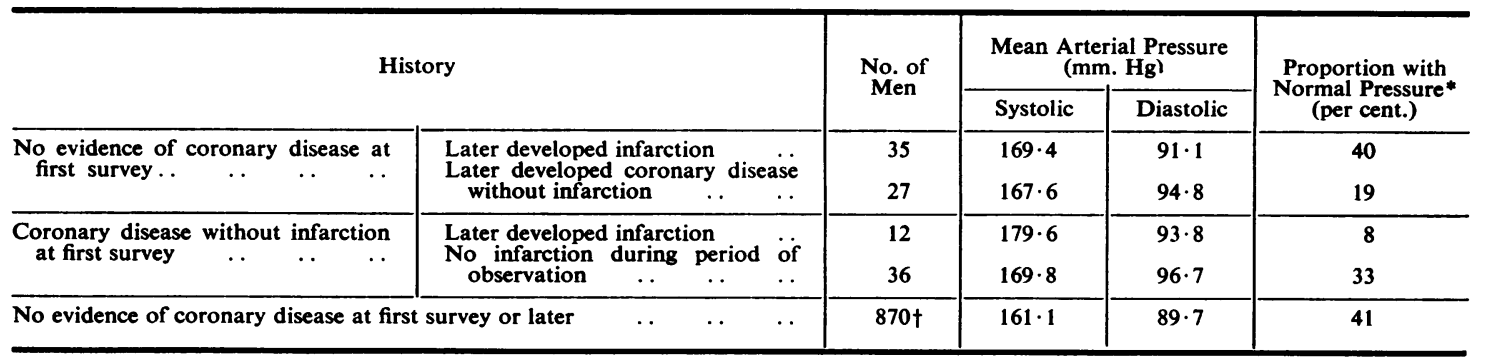

* Systolic pressure not greater than $150 \mathrm{~mm}$. $\mathrm{Hg}$ and diastolic pressure not greater than $90 \mathrm{~mm} . \mathrm{Hg}$.

t Excludes 28 men untraced and 13 whose pressures were not recorded at first survey.

5 years of the investigation and those who died. The mean pressures in these two groups were 168.9/93.7 and $171 \cdot 6 / 94.6 \mathrm{~mm}$. $\mathrm{Hg}$ respectively, and the proportions of men with "normal" pressures were 38 and 28 per cent.

\section{Discussion}

The importance of a disease is usually assessed in terms of prevalence, disability, and mortality. The measurement of prevalence and mortality, although not always easy, is relatively straightforward, but the assessment of disability is more difficult because it depends not only on the severity of the disease but on the demands of the occupation in which the individual is engaged. This could lead to the paradoxical situation that a disease may appear to be less disabling in an old man who has retired than in a younger person, but the position is complicated by the possibility that the disease may itself have contributed to the man's retirement. For these reasons no analysis of the present data in respect of disability has been attempted. There is, however, no doubt that coronary disease is usually a disabling condition in the sense that even in mild cases it imposes some restriction on the activities of the patient.

The prevalence of a disease, measured by the number of affected individuals at any time, is obviously influenced by the duration of the illness and by its fatality rate. Diseases of long duration and low fatality, such as arthritic conditions, will thus tend to be more prevalent than diseases which rapidly cause death. Since a number of cases of coronary disease progress very quickly to a fatal termination, estimates of prevalence viewed alone are of limited value, but they nevertheless have some interest and are shown in Table VII. Unfortunately the men were not examined clinically at the final follow-up in 1961 and the prevalence of the disease at that time is based partly on fact-the series
TABLE VII

PREVALENCE OF CORONARY DISEASE ACCORDING TO AGE

\begin{tabular}{|c|c|c|c|c|}
\hline Time & $\begin{array}{l}\text { Age } \\
\text { (yrs) }\end{array}$ & $\begin{array}{l}\text { No. } \\
\text { of Men } \\
\text { Alive }\end{array}$ & $\begin{array}{c}\text { No. with } \\
\text { Coronary } \\
\text { Disease }\end{array}$ & $\begin{array}{c}\text { Prevalence } \\
\text { of } \\
\text { Coronary } \\
\text { Disease } \\
\text { (per 100 } \\
\text { men) }\end{array}$ \\
\hline 1st survey (1956) & $60-69$ & 1,062 & 89 & $8 \cdot 4$ \\
\hline 2nd survey (1959) .. & $63-72$ & 925 & 101 & 10.9 \\
\hline $\begin{array}{l}\text { Final follow-up } \\
\text { (1961) }\end{array}$ & $65-74$ & 825 & $\left.\begin{array}{c}23 \text { esti- } \\
\text { mated * }\end{array}\right\} 107$ & $13 \cdot 0$ \\
\hline
\end{tabular}

* Estimated by applying the case fatality rate $(37.5$ per cent.) in $1956-59$ to the number of deaths (14) in 1959-61.

identified at the two previous surveys and known to be alive ( 84 men) - and partly on inference from the experience in the previous 3 years when 37.5 per cent. of new cases died. This proportion, when applied to the fourteen deaths which occurred in 1959-61, suggests that there were 37 new cases in the period, 23 of which would be expected to be alive in 1961. (This may well be an underestimate because it is based on the mortality experience of a 3-year period applied to the deaths which occurred in 2 years.) The results suggest that the prevalence of the disease increases with age; in other words, relative to the population at risk (which is of course dependent on mortality from other causes), new cases are arising faster than established cases are dying. This is consistent with the findings of another investigation in respect of older men (Edwards, McKeown, and Whitfield, 1959), which showed prevalence rates of $14 \cdot 8$ per cent. in men aged 70-74 and $18 \cdot 1$ per cent. in men aged 75 and over.

When assessing the importance of a disease in respect of its mortality, it is necessary to take account of age because it is mainly as a cause of premature death that a disease may be deemed important. The 
current death rates from coronary disease (Table I) show a very pronounced relationship with age-the rate roughly doubles every 5 years up to age 59 and at higher ages the absolute increments in successive quinquennia are even greater. Defining premature death as death before the age of 70 , we find that, in England and Wales in 1962, 28 per cent. of such deaths were ascribed to coronary disease. Its importance as a cause of death in middle life is further illustrated by the fact that one-quarter of all male deaths ascribed to it occurred in men under 60 and over a half in men under 70 years.

Although coronary disease usually results in death, sooner or later, mortality statistics alone do not give a true impression of liability to the disease. This is because doctors who certify death do not always distinguish between coronary disease and other forms of heart disease (this point is considered in the first part of this paper) and because men with coronary disease not infrequently die from some other cause before the coronary condition becomes fatal (eight of the 29 deaths of men found to have coronary disease at the first survey were due to other causes). But some estimate of liability to the disease can be obtained by combining mortality figures and prevalence rates in the following way.

The men aged 60-69 years at the first survey $(1,062$ including 89 with recognized coronary disease) were the survivors of a larger number which can be approximately estimated by applying the method of the life table to the appropriate age-specific mortality rates of the preceding periods. (National rates have been used because the local data are not sufficiently detailed; this is unlikely to lead to much error because Birmingham mortality rates do not usually differ appreciably from the national average.) We can thus reconstruct a cohort of men aged 40-44 which experienced losses by death at the rates prevailing at the appropriate times as they passed through successive age groups to reach age 60-69 in 1956. In the same way the number of deaths due to coronary disease suffered by this cohort can be calculated. It was considered unnecessary to extend the cohort back to ages earlier than $40-44$ because at that time very few deaths of younger men were ascribed to coronary disease. The estimated size of the cohort at age 40-44 was 1,533 men, of whom 471 died before the first survey, 75 of them from coronary disease. This is shown in the first row of Table VIII; the rest of the Table, compiled from the survey observations, follows the cohort up to age 65-74. The incidence of coronary disease (Column $x$ ) and the death rates from other causes $(y)$ are then applied in successive stages to a cohort of 1,000 men $(b)$, eliminating at each stage men who developed coronary disease $(c)$ and men who died from other causes $(d)$. This exercise indicates that, by age 65-74, 164 men out of 1,000 would have developed the disease. Of these 71 would be expected to be alive and 93 would have died, while 352 would have died from other causes.

This estimate of incidence is probably an understatement, because more than one-quarter of the total is based on mortality before the first survey and for the reasons given above this is likely to err on the conservative side. Furthermore, the high mortality rates in older men (shown in Table I) and their greater prevalence rates (shown by Edwards and

TABLE VIII

ESTIMATED INCIDENCE OF CORONARY ARTERY DISEASE IN MEN FROM AGE 40-44 TO 65-74 YEARS

\begin{tabular}{|c|c|c|c|c|c|c|c|c|}
\hline \multirow{2}{*}{ Time } & \multirow{2}{*}{ No. of Men at Risk (a) } & \multicolumn{2}{|c|}{$\begin{array}{l}\text { New Cases of } \\
\text { Coronary Disease }\end{array}$} & \multicolumn{2}{|c|}{$\begin{array}{l}\text { Deaths from } \\
\text { Other Causes }\end{array}$} & \multicolumn{3}{|c|}{$\begin{array}{l}\text { Experience of Cohort of } 1,000 \\
\text { from Age 40-44 }\end{array}$} \\
\hline & & No. & Per cent. $(x)$ & No. & Per cent. $(y)$ & $\begin{array}{l}\text { No. at } \\
\text { Risk (b) }\end{array}$ & $\begin{array}{l}\text { New Cases } \\
\text { of Coronary } \\
\text { Disease }(c)\end{array}$ & $\begin{array}{c}\text { Deaths from } \\
\text { Other } \\
\text { Causes }(d)\end{array}$ \\
\hline $\begin{array}{l}\text { Before First Survey (e) } \\
\text { First Survey (1956) } \\
\text { Interval 1956-59 } \\
\text { Second Survey (1959) } \\
\text { Interval 1959-61 } \\
\text { Final Follow-up (1961) }\end{array}$ & $\begin{array}{c}1,533 \\
1,062 \\
1,062-89-\frac{1}{2}(18)=964 \\
854 \\
854-30-\frac{1}{2}(10)=819 \\
741\end{array}$ & $\begin{array}{l}75 \\
89 \\
18 \\
30 \\
14 \\
23(f)\end{array}$ & $\begin{array}{l}4 \cdot 89 \\
8 \cdot 38 \\
1 \cdot 87 \\
3 \cdot 51 \\
1 \cdot 71 \\
3 \cdot 10\end{array}$ & $\frac{396}{83}$ & $\frac{25 \cdot 83}{8 \cdot \overline{6}} \overline{7 \cdot 20}$ & $\begin{array}{r}1,000 \\
693 \\
635 \\
568 \\
548 \\
500\end{array}$ & $\begin{array}{r}49 \\
58 \\
12 \\
20 \\
9 \\
16\end{array}$ & $\frac{258}{\frac{55}{39}}$ \\
\hline Total .. & . & 249 & & 538 & & 484 & 164 & 352 \\
\hline
\end{tabular}

Notes:

(a) Excluding men previously found to have coronary disease. Men untraced at end of period were assumed to be at risk for half the period.

(b) Survivors, excluding men previously found to have coronary disease.

(c) $b x \div 100$.

(d) by $\div 100$.

(e) Estimated from national mortality statistics (see Text).

$(f)$ Estimated as in Table VII. 
others, 1959) suggest that the incidence would be considerably more if these men were followed to an advanced age.

Finally, it should be emphasized that this figure is based on past experience and may not truly represent the present situation. If the incidence of coronary disease is increasing as rapidly as mortality statistics suggest, it seems likely that the men on which this investigation is based were, in middle life, less exposed to the causal influences of the disease than middle-aged men are to-day. If this is so, the figure given above underestimates the present importance of the disease.

\section{SUMMARY}

(1) Mortality statistics for men in England and Wales indicate that since 1950 the death rate ascribed to coronary artery disease has risen greatly. Some of the increase appears to be due to transfer from other causes of death, but a substantial part, in middle-age at least, is considered to be real.

(2) A survey in 1956 of 1,062 Birmingham men aged 60-69 years, identified 89 with coronary disease. 5 years later 31 had died. A second survey in 1959 revealed thirty new cases. In the interval eighteen other new cases had died and in the next 2 years fourteen more fatal cases occurred.

(3) Mean systolic and diastolic pressures, recorded at the first survey, of men who later developed the disease were higher than average. Almost onethird of them, however, had pressures which did not exceed $150 / 90 \mathrm{~mm}$. $\mathrm{Hg}$.

(4) Although mortality from the disease increases steeply with age, prevalence rates also increase, suggesting that new cases are developing faster than established cases are dying.

(5) From national mortality statistics combined with the survey data, it was concluded that 164 men out of 1,000 had been affected by age 65-74. Reasons are given for the belief that this estimate understates the present importance of the disease.

We are greatly indebted to the general practitioners who carried out the examinations of the subjects of these surveys, to the Birmingham Executive Council for help in tracing some of the men, and to the Endowment Fund of the United Birmingham Hospitals for a grant to cover the expenses of the inquiry.

\section{REFERENCES}

Brown, R. G., Davidson, L. A. G., McKeown, T., and Whitfield, A. G. W. (1957). Lancet, 2, 1073.

Campbell, M. (1963). Brit. med. J., 2, 712.

Edwards, F., McKeown, T., and Whitfield, A. G. W. (1959). Brit. J. prev. soc. Med., 13, 51.

Kannel, W. B., Dawber, T. R., Kagan, A., Revotskie, N., and Stokes, J. (1961). Ann. intern. Med., 55, 33.

Registrar General (1959). "Statistical Review of England and Wales for 1957". Pt. III, Appendix B. HMSO, London.

Yano, K., and Ueda, S. (1963). Yale J. Biol. Med., 35, 504. 